EPiC Series in Language and Linguistics
Volume 1, 2016, Pages 411-423
CILC2016. 8th International
Conference on Corpus Linguistics

\title{
Corpus Based Lexical Semantic Analysis of minimal pairs of deverbal adjectives with Spanish -dor/-nte suffix
}

\author{
Ryo Tsutahara ${ }^{1}$ \\ ${ }^{1}$ Tokyo University of Foreign Studies, Japan \\ r.tsutaharadtufs.ac.jp
}

\begin{abstract}
This paper shows the semantic differences and similarities between Spanish active deverbal adjectives with the -dor and -nte suffixes. Minimal pairs of derivatives with the suffixes will be quantitatively analyzed, as the patterns of modification are the center of the interest. This study concludes that the derivatives' modification patterns are parallel with the denotation patterns of nominal derivatives with the same suffixes.
\end{abstract}

\section{Introduction}

This paper aims to show semantic differences and similarities between Spanish active deverbal adjectives with the -dor and -nte suffixes. More specifically, I will quantitatively analyze minimal pairs of the deverbal adjectives for each suffix with the same base verb such as estimulador/estimulante (for the verb estimular 'to stimulate') and describe the typical modification patterns. Based on these analyses and descriptions, I will explain the semantic differences and similarities between two types of adjectives with similar functions.

Before starting the discussion, I will briefly explain the two suffixes in question. Both suffixes are attached to verbs forming adjectives and nouns: Fumar 'to smoke' > fumador, calmar 'to calm' $>$ calmante. The second resemblance is that they are syntactic-semantically active. They are called "active" because they modify nouns that represent entities corresponding to the subject of base verbs or denote such subjective entities. They therefore do not only denote or modify AGENT but also entities that can correspond to the subject of base verbs, like INSTRUMENT, CAUSE, EXPERIENCER and so on. For these reasons, the deverbal adjectives in question are replaceable with relative pronoun constructions que $V$ 'that $\mathrm{V}$ ', as in the examples below.

(1) El jefe jumador $>$ El jefe que fuma 'the boss that smokes'

(2) El fármaco calmante de dolor > El fármaco que calma dolor 'the medicine that calms pain' 
For these reasons, they are considered as active and similar. However, their characteristics and functions are not completely identical. For example, there are verbs that each suffix cannot attach to: matador/*matante (with the verb matar 'to kill') and *sobrevividor/sobreviviente (with the verb sobrevivir 'to survive'). Curiously, there are minimal pairs of deverbal adjectives with both suffixes whose base verbs are identical, like picador and picante (with the verb picar 'to sting'). However, the two adjectives' use is not always the same. For example, picador usually modifies nouns representing instruments such as drills, blades, and knives (martillo/cuchilla picador(a) 'hammer/blade that stings'), while picante is used to modify materials like chili (aji/pimentón picante 'pepper/paprika that is hot). In these contexts, the two deverbal adjectives are not substitutable: *matrillo picante and *aji picador. This is why the two suffixes are considered to be similar, but not same.

The two suffixes are still productive and the difference between them has been discussed in several antecedent works. However, it seems that this question is not completely addressed, especially because there are very few works focusing on the semantic difference between the two deverbal adjective types. A main reason for this may be the lack of adequate resource for analyzing the modification or the collocation patterns of deverbal adjectives. The two suffixes also form deverbal nouns and in many cases, such nouns have been chosen mainly as the object of the analysis to consider the semantic difference between the two suffixes. There can be various explanations but the principle one is how deverbal nouns analyses are methodologically simpler. There are dictionaries containing deverbal nouns ' meanings, which make objective semantic analyses possible. On the contrary, as for the semantic difference between adjectives, it has been considered that the semantic difference should appear as the different patterns of modification or differences of semantic types of modified nouns. In other words, it is assumed that through analyzing the modification patterns of the derivatives for both suffixes, the semantic difference between them could be explained. However, such study has yet to be completed. One explanation for this could be how there was no objective resource to examine the modification patterns. For example, dictionaries do not contain information on the typical modification patterns of deverbal adjectives. The lack of an objective methodology made it difficult to describe the typical collocation patterns of each deverbal adjective with the suffixes in question. Laca (1993) and Cano (2013) proposed the typical modification patterns but their analysis were based on intuition and introspection; empirical examination is therefore necessary.

To solve this problem, I will analyze the two adjective types using a corpus and then differentiate them through empirical arguments. For the analysis, I will use the esTenTen corpus. The object of analysis is minimal pairs of deverbal adjectives like picador/picante. I will mainly focus on the modification patterns and the noun types the deverbal adjectives modify. The hypothesis is that each adjective will show different modification patterns, which is attributed to the variation in the two suffixes' semantic nature.

\subsection{Hypothesis and antecedent works}

This study describes the different modification patterns of the two deverbal adjective types. I will explain the noun types each deverbal adjective can and cannot modify. The discussions will help address the hypothesis that each adjective's modification pattern parallels the denotation distribution of the suffix's deverbal nouns.

For example, there is a minimal pair of deverbal adjectives secador/secante (both adjectives are from secar 'to dry') and the noun máquina 'machine' (abstractly labeled as INSTRUMENT) can only be modified by secador 'that dries': máquina secadora 'drying machine', *máquina secante. Both adjectives can be used as nouns, but only the secador denotes machines or INSTRUMENT and secante cannot. The noun secante, only represents materials, or CAUSE: un secador 'a dryer, a drying machine' and un secante 'blotting paper.' The entities corresponding to INSTRUMENT can only be denoted and modified by -dor derivatives and -nte derivatives rarely do so. This is the parallelism that I try to defend. 
This assumption is not particularly novel. For example, Laca (1993), one of the most influential studies on the semantic difference between the two suffixes implicates this parallelism.

As discussed, there are several antecedent works on the semantic difference between deverbal nouns with the two suffixes (Beniers (1992), Laca (1993), Rifón (1997), Cano (2013), Tsutahara (2014), etc.).

In Tsutahara (2014) all the deverbal nouns with two suffixes attested more than once after 20th century in the Corpus del español corpus were analyzed and classified with denotations of deverbal nouns in the following 6 classes:

CAUSATIVE AGENT: Agents who cause change to objects

INSTRUMENT: Artifacts used by agents that causes change to objects

NON-CAUSATIVE AGENT: Agents who do not cause change to objects

CAUSE: Entities that cause change to objects without control of the action

NON-AGENT: Animate entities in some state

PATIENTIVE: Entities corresponding to the subjects of unaccusative verbs

According to Tsutahara (2014), the two types of deverbal nouns are in different distributions. The analysis in Tsutahara (2014) can be summed up in Table 1.

\begin{tabular}{|c|c|c|c|}
\hline semantic role & dor & nte & \\
\hline CAUSATIVE AGENT & *** & & \\
\hline INSTRUMENT & $* * *$ & & ***: typically denotes \\
\hline NON-CAUSATIVE AGENT & $* *$ & $* *$ & **: can denote \\
\hline CAUSE & $* *$ & $* * *$ & \\
\hline NON-AGENT & $*$ & $* *$ & *: rarely denotes \\
\hline PATIENTIVE & & ** & WQ mark: hardly denotes \\
\hline
\end{tabular}

Table 1. Distribution of deverbal nouns with - dor \& -nte

As apparent above, the typical denotation of each derivative is different. The -dor nouns typically represent CAUSATIVE AGENT \& INSTRUMENT transformador 'transformer') and -nte nouns rarely represent such entities. This can be considered as one of the principal semantic differences between the two suffixes.

On the contrary, non-agentive entities (e.g., NON-AGENT and PATIENTIVE) are denoted almost exclusively by nouns with -nte (e.g., restante 'what is left'). This distribution also differentiates the two suffixes.

Table 1 shows both the difference and similarities between the two types of nominal derivatives. According to the table, both types can denote entities corresponding to NON-CAUSATIVE AGENT, CAUSE, and NON-AGENT (although -nte deverbals seem to be vinculated more strongly with the latter two types).

This study's preliminary assumption is that the distribution of the two deverbal nouns' denotations and the modification patterns of the deverbal adjectives with the same suffixes are identical. From the description in Tsutahara (2014), hypothesis for this research was thus formed. The following hypotheses will be tested in this study.

1. The deverbal adjectives with -dor can modify nouns denoting entities corresponding to the CAUSATIVE AGENT \& INSTRUMENT of the actions denoted by base verbs, while the deverbal adjectives with -nte cannot. 
2. The deverbal adjectives with -nte can modify nouns denoting PATIENTIVE entities of the actions denoted by base verbs, while the deverbal adjectives with -dor cannot.

3. Both types of adjectives can modify nouns denoting entities corresponding to NONCAUSATIVE AGENT and CAUSE of the actions denoted by base verbs.

\section{Methodology}

The object of this analysis is the minimal pairs of deverbal adjectives with the two suffixes like estimulador/estimulante (from the verb estimular 'to stimulate'). I will specify and observe the modified nouns tied strongly to each of the deverbal adjectives as a collocation. Based on this analysis and each collocation pattern, I will try to explain the difference between the two types of adjectives. In such minimal pairs, the two types of adjectives are differentiated by the suffixes attached to them. If a semantic difference is observed, it may be attributed to the suffixes' different semantic natures. It is therefore possible to specify how the two suffixes work semantically in deverbal adjectives. This is why such minimal pairs are the focus of this analysis. In this section, I will explain how I gathered the minimal pairs and analyzed them.

\subsection{Minimal pairs}

To gather the minimal pairs of deverbal adjectives, I initially identified all the adjectival derivatives with -dor, its allomorph -tor, -sor, -or ${ }^{*}$, and -nte, which have been used more than once since $20^{\text {th }}$ century in the Corpus del español. From that list of adjectival derivatives, minimal pairs were extracted. I then identified 40 minimal pairs in which the use of derivatives with each suffix is attested more than 1000 times in the esTenTen corpus, where this study's analysis will be conducted. This study subsequently only analyzed high-frequency derivatives. This is because for an accurate empirical analysis, a certain quantity of data was needed.

The minimal pairs of the following base verbs were analyzed in this study.

${ }^{*}$-tor, -sor, -or are variants of -dor. 


\begin{tabular}{|c|c|c|c|}
\hline & dor (raw frequency) & nte (raw frequency) & total \\
\hline integrar 'to integrate' & 47885 & 193942 & 241827 \\
\hline gobernar 'to govem' & 127048 & 42430 & 169478 \\
\hline dom nar 'to dom nate' & 6370 & 154342 & 160712 \\
\hline conservar 'to conserve' & 145449 & 4352 & 149801 \\
\hline vis itar 'to v is it' & 2352 & 106090 & 108442 \\
\hline contam inar 'to contam inate' & 3562 & 87374 & 90936 \\
\hline cantar 'to sing' & 6636 & 60804 & 67440 \\
\hline portar 'to carry' & 50136 & 3994 & 54130 \\
\hline operar 'to operate' & 44532 & 4636 & 49168 \\
\hline estm u lar 'to stm u late' & 2941 & 36723 & 39664 \\
\hline lim itar 'to lim it' & 2576 & 35030 & 37606 \\
\hline asp irar 'to vacuum , asp irate' & 1853 & 33580 & 35433 \\
\hline am enazar 'to threaten' & 9303 & 24636 & 33939 \\
\hline triunfar 'to trium ph' & 11220 & 17444 & 28664 \\
\hline m otivar 'to m otivate' & 21653 & 4300 & 25953 \\
\hline donar'to donate' & 2243 & 20439 & 22682 \\
\hline cortar 'to cut' & 3708 & 18360 & 22068 \\
\hline contar 'to count, te ll' & 16843 & 3961 & 20804 \\
\hline a is lar 'to isolate' & 1441 & 17865 & 19306 \\
\hline tranquilizar 'to ca m' & 9944 & 4554 & 14498 \\
\hline navegar 'to nav igate' & 6809 & 6154 & 12963 \\
\hline em briagar 'to m ake drunk' & 2639 & 9549 & 12188 \\
\hline volar 'to fly' & 6736 & 5222 & 11958 \\
\hline deslizar 'to slide' & 2100 & 9491 & 11591 \\
\hline observar 'to observe' & 9969 & 1478 & 11447 \\
\hline cautivar 'to captivate' & 5929 & 4037 & 9966 \\
\hline secar 'to dry' & 7531 & 2047 & 9578 \\
\hline gbbalizar 'to g bbalize' & 7042 & 1618 & 8660 \\
\hline estabilizar 'to stabilize' & 7148 & 1007 & 8155 \\
\hline detonar 'to detonate' & 2046 & 6103 & 8149 \\
\hline cargar 'to carry' & 6677 & 1396 & 8073 \\
\hline avasallar 'to push around' & 4818 & 3181 & 7999 \\
\hline discrm nar 'to discrim nate' & 5067 & 2648 & 7715 \\
\hline certificar 'to certificate' & 6032 & 1091 & 7123 \\
\hline b bquear 'to b bck' & 3643 & 3041 & 6684 \\
\hline tota lizar 'to tota lize' & 5233 & 1412 & 6645 \\
\hline socializar'to socialize' & 3586 & 1220 & 4806 \\
\hline perforar 'to drll, cross' & 2665 & 1468 & 4133 \\
\hline quem ar 'to bum' & 2037 & 1330 & 3367 \\
\hline m ora lizar 'to m ora lize' & 1407 & 1936 & 3343 \\
\hline total & 616809 & 940285 & 1557094 \\
\hline
\end{tabular}

Table 2. Objects of the analysis 


\subsection{Sketch Engine -Word Sketch Differences function-}

The gathered minimal pairs were analyzed in the esTenTen corpus. This corpus was chosen for its size $(9,497,402,122$ words). To the best of the author's knowledge, this is one of the largest Spanish corpus and in the study of collocation patterns, it is assumed that the bigger the corpus size is, the more confident/accurate the analysis will be. This is why this corpus was chosen for this study.

For the analysis, the analytic function "Word Sketch Differences" was employed. The function is explained to show "those patterns and combinations that the two items have in common, and also those patterns and combinations that are more typical of, or unique to, one word rather than the other (manual of the corpus)." By using this function, the two adjectives are analyzed simultaneously and the program shows the typical nouns modified by each type. Based on this data, I tried to describe the modification patterns of each type of deverbal adjectives and address the hypotheses. The corpus provides a ranking of typical nouns modified by each of the two adjectives. The commonness is measured by the logDice score ${ }^{\dagger+}$.

For example, the minimal pair limitador/limitante (from the verb limitar 'to limit') is analyzed as follows in the corpus.

\section{limitador / limitante estenten [2011, Eu+ Am, Freeling va] freas $=2.576 \mid 35,030$}

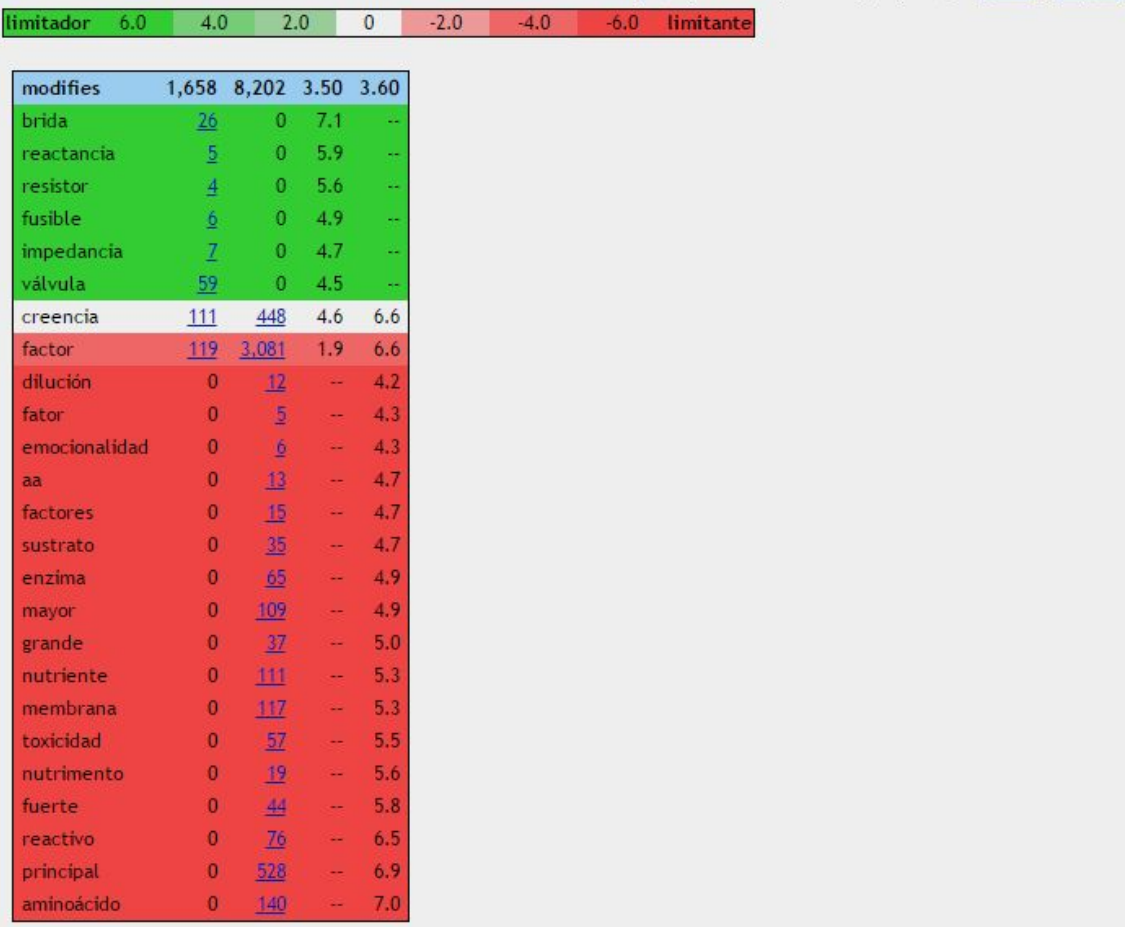

Figure 1. analysis of limitador/limitante

\footnotetext{
$\dagger$ The score is calculated from the Dice score and the score is computed from the frequency of occurrence of two words and the frequency of co-occurrence of the two words. The score is reliable for measuring the strength of association between two words. However, the Dice score is sometimes to be understood. Rychlý (2008), when evaluating it as a reasonable measure, pointed out a problem, where the values are usually very small. This author thus proposed to use the logarithm. The logarithmized score is the logDice (cf. Rychlý (2008): 9); this score is much easily understood and is convenient for discussion.

\# A ranking based on the row frequency is also available.
} 
In the green part, nouns vinculated strongly with limitador (or only modified by the -dor adjective) are listed and are organized based on their logDice score. In the white part, nouns modified by both adjectives are shown, while the red lists nouns modified exclusively by limitante. From these data, it is possible to consider not only the difference but also the similarity in the modification patterns. By analyzing these tables, the hypotheses were examined.

\section{Analysis}

It seems that the analysis revealed a parallelism between the denotation patterns of the nominal derivatives with the two suffixes and the modification patterns of the adjectival derivatives. The analysis thus supported the hypotheses. In the following subsections, I will present some of the minimal pair analyses.

\section{1 limitador/limitante}

For the verb limitar 'to limit,' both suffixes can be used to form the adjectival minimal pair limitador/limitante 'that limits, limiting.' Both derivatives seem to be synonymous but according to the analysis, each derivative modifies different types of nouns.

First, as hypothesized, only limitador modifies nouns corresponding to INSTRUMENT. Examples (which include the logDice scores in brackets) include brida 'bridle' (7.1), fusible 'fuse' (4.9), and impedencia 'impedence' (4.7). Among the nouns typically modified by limitante, INSTRUMENTAL nouns were not found.

On the other hand, many nouns typically modified by limitante are chemical materials or medicine (thus corresponding to CAUSE or PATIENTIVE entities), such as aminoácido 'amino acid' (7), reactivo 'reagent' (6.5), and nutrimento 'nutriment' (5.7). Remember that deverbal nouns with the -nte suffix typically denote these entities. In other words, patterns of denotation and modification for limitador/limitante are parallel.

In short, the parallelism and different modification patterns occur as predicted in the hypotheses.

\section{2 estabilizador/estabilizante}

Like the minimal pair limitador/limitante, there is a pair from the verb estabilizar 'to stabilize something' namely estabilizador/estabilizante. In dictionaries, the two derivatives are synonymous and mean an object or a person "that stabilizes something." However, according to our observation, their modification patterns are different.

As predicted, among the nouns modified by estabilizador, nouns corresponding with INSTRUMENT were found. The noun with the highest logDice score was barra 'bar' (7.6). The NP barra estabilizadora denotes a stabilizing bar, where the bar can be considered an INSTRUMENT with which an AGENT can stabilize something. Aleta 'flap' (5.7), tobillera 'ankle support' (4.6), and resorte 'suspender' (2.7) are also modified exclusively by estabilizador; all of them are considered an INSTRUMENT.

On the contrary, there is only one salient noun modified by the estabilizante adjective, namely ampolla 'ample.' Obviously, this is not an INSTRUMENT but instead corresponds with CAUSE.

As was observed in limitador/limitante, this pair demonstrates the same type of contrast, such that only the -dor adjectives modify INSTRUMENTAL entities. 


\section{3 perforador/perforante}

The verb perforar 'to drill something, to cross' is the base verb for the minimal pair: perforador/perforante. The different modification pattern of each adjective is also suggestive.

As seen in previous examples, among the salient nouns modified by perforador, INSTRUMENTAL nouns were found; examples include martillo 'hammer' (8), máquina 'machine' (6.4), barrena 'drill, gimlet' (6.3), and broca 'bit (of drill)' (6). However, apart from these INSTRUMENTAL nouns, some animate nouns are also found, such as poliqueto 'polychaete, anneilid worms' (6.9) and escarabajo 'scarab' (5.1). Obviously, these insects are not an INSTRUMENT but are CAUSATIVE AGENTS. Despite being non-human, insects make holes and have control over this action.

On the contrary, among the nouns modified saliently by perforante, INSTRUMENTAL and AGENTIVE nouns were not found. As in the former cases, the modified nouns correspond with CAUSE, such as arteria 'artery' (6.5), tálamo 'thalamus' (6.3), and vena 'vein' (4.9). These nouns are modified by perforante because they cross fascia.

\section{4 secador/secante}

In the pair secador/secante, from the verb secar 'to dry something,' the unique modification pattern for -nte adjectives was observed.

At first, secador (like former -dor adjectives) modifies INSTRUMENTS: tolva 'hopper, chute' (5.6), filtro 'filter' (4.1), and rodillo 'roller' (3.1).

Such INSTRUMENTAL nouns were not found among nouns saliently modified by secante adjective. Instead, CAUSE nouns were found. For example, talco 'talcum powder' (5.6) and papel 'paper' (4). Modified by secante, these nouns denote materials that can dry something. Besides these, the noun aceite 'oil' (3.1) was also found. However, aceite secante does not denote 'oil to dry something' but rather 'drying oil,' namely oils "that hardens to a tough, solid film after a period of exposure to air (Wikipedia)." Secante in aceite secante is therefore considered to be derived from the pronominal or intransitive version of the verb secar 'to dry out (intransitive).' The noun aceite is thus considered PATIENTIVE; PATIENTIVE nouns are only saliently modified by -nte adjectives and never by -dor adjectives. Note that this contrast also supports the parallelism being examined. In previous works, it was confirmed that between -dor and -nte nouns, only -nte nouns could denote such entities (see Table 2).

\section{5 cautivador/cautivante}

The Word Sketch Differences function can detect both the salient modification patterns as well as nouns that can be modified by both adjective types. Among the pairs of deverbal adjectives analyzed, cautivador/cautivante from the verb cautivar 'to captivate, attract something' showed the widest variety of such nouns: melodía 'melody'/-dor: 2.7, -nte: 1.6, encanto 'charm'/-dor:2.2, -nte:1.2, mirada 'look'/-dor: 2.5, -nte:1.6, fragancia 'fragrance'/-dor: 3.5, -nte: 2.7, paisaje 'landscape'/ -dor:2.2, -nte: 1.4, perfume 'perfume'/-dor: 2.2, -nte:1.4, aroma 'aroma'/-dor:2.3, -nte: 2, belleza 'beauty'/-dor: 2.1, nte: 1.9, frescura 'freshness'/-dor: 1.9, -nte: 1.9, prosa 'prose'/-dor: 2.6, -nte: 3.2. Curiously, all these nouns denote entities corresponding with CAUSE. For example, a melody captivates someone without the participation of an AGENT.

This result can also be predicted from the hypothesis. Remember that deverbal nouns with both suffixes could denote causal entities at certain frequencies (cf. Table 2). In other words, as there is a parallelism between the denotation pattern of nominal -dor/-nte suffixes and the modification patterns of adjectival -dor/-nte suffixes, it can be assumed that both adjective types can modify these entities. 
In the 40 minimal pairs analyzed in this study, 85 nouns that can be modified saliently by both deverbal adjective types were detected. The majority of these nouns (i.e., 60 nouns) were analyzed as CAUSE. This fact supports the assumption that derivatives with both suffixes can denote and modify CAUSE, thus serving as a similarity between the two adjective types.

The majority of nouns typically modified by both adjective types have the semantic role CAUSE; the second biggest group was formed by abstract nouns like efecto 'effect.' However, this type of collocation cannot be analyzed in the same way because when the deverbal adjectives modify these nouns, they are in the relational rather than active use.

This relational use is syntactic and semantically different from its active counterpart. For example, the deverbal adjectives in active use can be paraphrased as que $V$ 'that $\mathrm{V}^{\prime}$ ' jefe fumador $>$ jefe que fuma 'boss that smokes.' On the contrary, when they modify abstract nouns (i.e., in relational use), they cannot be paraphrased in this way but are instead phrased as de $V$ 'of Ving': efecto tranquilizador/tranquilizante $>$ *efecto que tranquilizalefecto de tranquilizar 'effect of paralyzing, paralyzing effect.' As seen in this paraphrase pattern, the nouns modified by the deverbal adjectives do not correspond with the subject of the base verbs' action. For these reasons, this study separates deverbal adjectives in relational use as our objective is to describe modification patterns of active deverbal adjectives. For the more detailed discussion on relational deverbal adjectives, see Rainer \& Wolborska (2012) and Tsutahara (2015a, b).

In summary, it was confirmed that 85 noun types can be modified by the two deverbal adjective forms originating from the same base verbs. The largest majority of such nouns have the semantic role CAUSE (60 of 85 nouns) and the second group was abstract nouns (10 of 85), however the latter should be addressed separately. It would be possible to conclude that the two adjective types are more semantically similar when they modify nouns denoting entities corresponding with CAUSE or abstract nouns.

\subsection{Recapitulation}

The analyses found a semantic difference between two types of deverbal adjectives, as it was shown that only -dor adjectives modify CAUSATIVE AGENT and INSTRUMENT nouns. It is considered that this is because the -dor suffix favors these entities, while the -nte suffix does not. In 27 of the 40 minimal pairs analyzed in this study, this contrast was observed. See the following table. 


\begin{tabular}{|c|c|}
\hline Derivatives & M od ified CAUSAT NE AGENT \& NSTRUMENT \\
\hline operador to operate' & brazo ám'/3.6 N STRUMENT \\
\hline secador to dry' & $\begin{array}{l}\text { to lva hopper' } / 5.6 \text {, cilindro ćy linder' } / 4.4 \text {, filtro filter' } / 4.1 \text {, sib } \\
\text { śib' } / 3.9 \text {, estufa śtove' } / 3.1 \text {, rod ilb roller' } / 3.1 \text {, máqu ina } \\
\text { ḿ ach ne' } / 2.7 \text {, N STRUM EN T }\end{array}$ \\
\hline cortador to cut' & 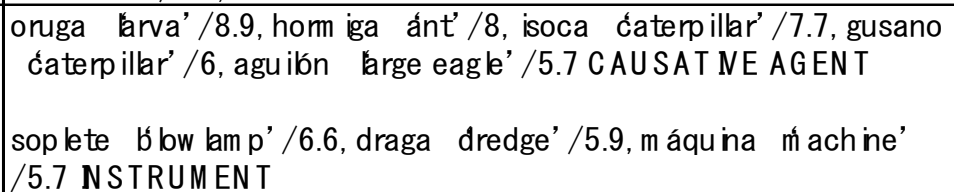 \\
\hline certificar certificate’ & $\begin{array}{l}\text { veternario veterinary' } / 2, \text { m édico doctor' } / 0.9 \text { CAUSAT NE } \\
\text { AGENT }\end{array}$ \\
\hline estab ilizador to stab ilize' & $\begin{array}{l}\text { barra b́ar' /7.6, a leta f́lap' /5.7, tob illera ánkle support' /4.6, } \\
\text { paraca ída ṕarachute' /4.4, resorte śuspender' / } 2.7 \text { N STRU M EN T }\end{array}$ \\
\hline conservador to conserve' & $\begin{array}{l}\text { político po litic ian' /5.7, caud ilb leader'/5.3, cand idato } \\
\text { ćand idate' /5.3 CAUSAT NE AGEN T }\end{array}$ \\
\hline b bqueador to b bck' & $\begin{array}{l}\text { lengüeta reed' /5.2, pemo b́olt' } / 4.4 \text {, po lea ho ist' } / 4.3 \text {, re lé } \\
\text { re lay' / } 4.1 \text { N STRUM EN T }\end{array}$ \\
\hline cargador to charge' & 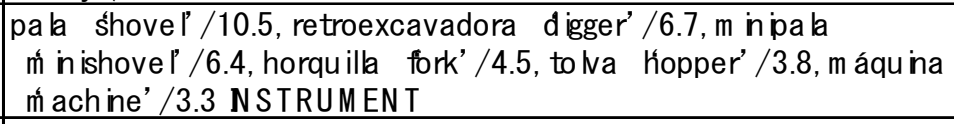 \\
\hline m otivador to m otivate' & $\begin{array}{l}\text { conferenc iante śpeaker' /4.6, conferenc ista śpeaker'/3.3 } \\
\text { CAUSAT NE AGEN T } \\
\text { palanca 'ever' } / 2.8 \text {, resorte śpring' / } 2.3 \text { N STRUM EN T }\end{array}$ \\
\hline perforador to drill, sting' & 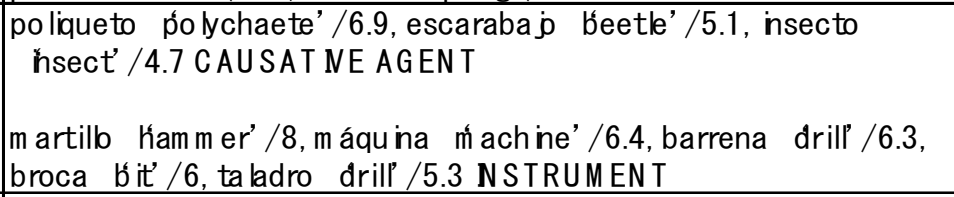 \\
\hline g bbalizador to g bba lize' & cap ita lista ćap ita lista' / 3.2 C AU SAT NE AGEN T \\
\hline integrador to integrate' & m aestro teacher' /5.3 CAUSAT NE AGEN T \\
\hline socializador to socialize' & $\begin{array}{l}\text { agente ágent' /4.4 CAUSAT NE AGEN T } \\
\text { instrum ento ho htrum ent' / } 0.1 \text { N STRUM EN T }\end{array}$ \\
\hline contador to count' & $\begin{array}{l}\text { perito śpecialist' } / 9.4 \text {, bacea éxecutor' /4.6 CAU SAT NE AGENT } \\
\text { báscula ścale' / } 4.4, \text { m áqu ina mach ine' /3.6 N STRUM EN T }\end{array}$ \\
\hline tota lizador to to ta lize' & contador counter' /4.5 N STRUM EN T \\
\hline quem ador to burn' & 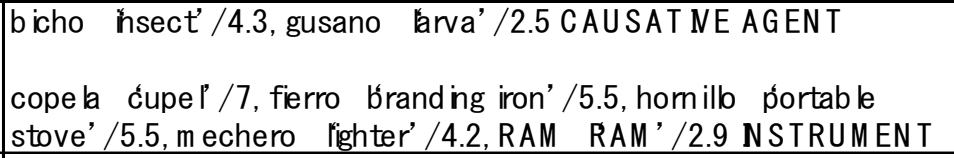 \\
\hline a is lador to iso late' & buje hub’ $/ 6.5$ NSTRUM EN T \\
\hline detonador to detonate' & $\begin{array}{l}\text { p isto la ṕ istol' /5.3, revólver revolver'/5.2, p istón/ ṕ iston' /4.3 } \\
\text { NSTRUM EN T }\end{array}$ \\
\hline Im itador to lim it' & 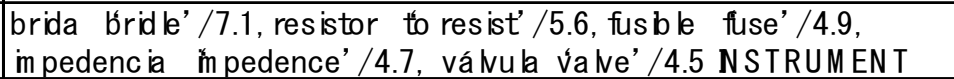 \\
\hline am enazador to threat' & ogro ǵiant' /3.9 CAUSAT NE AGENT \\
\hline asp irador to asp irate' & $\begin{array}{l}\text { barredora św eeper' /8.6, robot robot'/6.9, irrigador sprinkler' } \\
\text { /6.1 NSTRUM EN T }\end{array}$ \\
\hline estimulador to stimulate' & v brador to v brate' /5.6 NSTRUM EN T \\
\hline
\end{tabular}

Table 3. CAUSATIVE AGENT\& INSTRUMENT modified uniquely by -dor adjectives 
On the contrary, the PATIENTIVE nouns were only found among the nouns typically modified by -nte adjectives and -dor adjectives never modify such entities. In the following pairs, this contrast was observed.

\begin{tabular}{|c|c|}
\hline Derivatives & M odified PAT EN T NE entities \\
\hline Im itante to lim it' & am noác ido ám no ac id' $/ 7$, nutrim iento nutrim ent' $/ 5.6$ \\
\hline secante to dry' & ace ite ó il /3.1 \\
\hline deslizante to slide' & $\begin{array}{l}\text { anticaída fall protection' } / 7.1 \text {, com puerta hatch' } / 6.4 \text {, tapa ćover' } \\
/ 6.0 \text {, tac le tackle' } / 5.2 \text {, vector vector' } / 5.2 \text {, to do śunshade' } / 5.2 \text {, } \\
\text { acoplam iento docking' } / 4.9 \text {, em brague ć cuch' } / 4.9 \text {, pistón ṕiston' } \\
/ 4.9 \text {, carcasa fram e' } / 4.8 \text {, bande g tray' } 4.7\end{array}$ \\
\hline vo lante to $\mathrm{fly}^{\prime}$ & cenża ásh' / 8.4 \\
\hline
\end{tabular}

Table 4. PATIENTIVE entities modified uniquely by -nte adjectives

It was shown that the both adjective types sometimes modify the same nouns and the majority of such nouns correspond to CAUSE. This fact can be considered as a similarity between the two adjective types.

\section{Conclusion and future tasks}

This study demonstrated that there is a parallelism between patterns of denotation and modification of two derivative types.

As discussed, the existence of this parallelism was assumed in the literature but never examined empirically. The principal contribution of this study is therefore examining the hypotheses proposed in many antecedent works.

In addition, this study, among the studies of semantics of word formation with the suffixes -dor/-nte, can be characterized as the complementary study. Many of the arguments in the literature on this issue are based on type frequency analysis (e.g., Tsutahara (2014)). As was presented, Tsutahara (2014) stated that CAUSATIVE AGENTS and INSTRUMENTS are typical denotation of deverbal nominals with dor because most animate denotations of deverbal -dor nominals correspond to CAUSATIVE AGENT. The study concluded that the -dor suffix is a suffix that favors highly agentive entities. However, the author points out that the study is based on the type frequency and analysis from other perspectives would therefore be necessary to ensure his conclusion, as many nominal derivatives with the two suffixes are highly polysemous. For example, a deverbal noun revelador, from the verb revelar 'to reveal', denotes "someone who reveals secret (CAUSATIVE AGENT)" and also "liquid for photos or developer (CAUSE)". Therefore, it might be possible, for example, that -dor nouns denote CAUSE more frequently and denote CAUSATIVE AGENT very rarely (although it is grammatically possible). If so, it will not be adequate to describe that $-d o r$ is a suffix that prototypically denotes CAUSATIVE AGENT. In this sense, Tsutahara (2014) concluded that an examination from other perspective would be necessary.

This study is therefore "an examination from other perspective." In this study, the deverbal adjectives were individually analyzed (remember that the unit of the analysis in Tsutahara (2014) were more general, "nouns with -dor suffix"), typical patterns of modification of limited number of adjectival derivatives were treated. This study is thus based on the token frequency of deverbal adjectives.

This study therefore affirmed the first two hypotheses. 
1. The deverbal adjectives with -dor can modify nouns denoting entities corresponding to CAUSATIVE AGENT \& INSTRUMENT of the actions denoted by base verbs and the deverbal adjectives with -nte cannot.

2. The deverbal adjectives with -nte can modify nouns denoting entities corresponding to PATIENTIVE entities of the actions denoted by base verbs and the deverbal adjectives with dor cannot.

Curiously, these findings are parallel with the description in antecedent works and as it is emphasized, the analysis was done from the other perspectives. Therefore, it is possible to conclude that the result of the analysis in this study supports the descriptions already done in antecedent works. The analyses based on the type frequency in the literature and an analysis based on token frequency made in this study both indicate that the two suffixes denote or modify entities corresponding with subjects of base verbs; however, each suffix favors different types of subjects. The -dor suffix prefers highly agentive entities like CAUSATIVE AGENT and INSTRUMENT and -nte rarely combines with such types of subjects. On the contrary, -nte favors less agentive subjects like CAUSE, especially, denotation or modification of PATIENTIVE entities, which are extremely low agentive, is a unique function of nte.

As for the hypothesis 3 , it would be necessary some more examination.

3. Both types of adjectives can modify nouns denoting entities corresponding to NONCAUSATIVE AGENT and CAUSE of the actions denoted by base verbs.

The analysis revealed that both adjective types can denote entities with CAUSE, even sometimes modifying same nouns corresponding with CAUSE. It is therefore possible to conclude that one of the semantic resemblances between two suffixes is to denote and modify CAUSE.

However, from antecedent works, it was supposed that both types of adjectives would modify not only CAUSE but also NON-CAUSATIVE AGENT and this supposition was not examined because among the analyzed cases, such cases in which two adjectives modify same nouns that denote NONCAUSATIVE AGENT were not found. However, it seems impossible still to reject the assumption (I have analyzed only 40 minimal pairs.). So extending the data and examination of the modification of NON-CAUSATIVE AGENT will be one of the biggest tasks in the future to complete the description.

\section{References}

Beniers, E. (1992). Los nombres de agente. Estudios de lingüistica aplicada, 15-16, 11-20.

Bosque, I. (dir). (2005). Redes: Diccionario combinatorio de español contemporáneo. Madird. Ediciones SM. (REDES)

Cano Cambronero, M. (2013). Las derivaciones en -nte y -dor: estructura argumental y complejidad sintáctica en una morfología neoconstruccionista. Tesis doctoral. La Universidad Autónoma de Madrid.

Laca, B. (1993). Las nominalizaciones orientadas y los derivados españoles en"-dor" y"-nte". En Varela, S. (eds.) La formación de las palabras, 180-204. Madrid. Taurus.

Rainer, F. (1999). Derivación adjetival. En I. Bosque, and V. Demonte (Eds.). Gramática descriptiva de la lengua española (pp. 4595-4644). Madrid. Espasa Calpe. 
Rainer, F. \& Wolborska-Lauter, J. (2012). El uso relacional del sufijo -dor/-dora en español y su relación con el francés. Romanische Forschungen, 124 (3), 303-324.

Rifón, A. (1997). Sinonimia y polisemia de los sufijos -dor y -nte. Revista de lexicografía, 3, 95-108. Rychlý, P. (2008). A lexicographer-friendly association score. Proceedings of Recent Advances in Slavonic Natural Language Processing, RASLAN, 6-9.

Sketch engine. esTenTen [2011, Eu + Am, Freeling v4] $(9,497,402,122$ palabras $)$. https://the.sketchengine.co.uk/bonito/run.cgi/first_form?corpname=preloaded/estenten11_freeling _v4_virt;align $=.(15 / 1 / 2016)$.

Tsutahara, R. (2014). Los nombres en -dor y -nte y causatividad. Estudios Interlingüisticos, 2, 149-161.

Tsutahara, R. (2015a). Adjectival Derivatives with the Spanish Suffix -nte: Active and Non-active Uses. Procedia - Social and Behavioral Sciences, 198, 479-486.

Tsutahara, R. (2015b). Los usos no agentivos de adjetivos deverbales en -dor y -nte -su origen y espontaneidad-. Actas de Problemas actuales de la lingüistica ibero-románica, 1, 24-32. 